\title{
What are cleats? Preliminary studies from the Konin lignite mine, Miocene of central Poland
}

\author{
Marek Widera \\ Institute of Geology, Adam Mickiewicz University, Maków Polnych 16, 61-606 Poznań, Poland; \\ e-mail: widera@amu.edu.pl
}

\begin{abstract}
Cleats (fractures, joints) are discontinuities in coals, including lignites. They are important in mining activity because of their gas and water permeability in hard coal, and mainly because of their water permeability in lignites. As opposed to hard-coal cleats, lignite cleats have not been studied in detail before. The present contribution does so, using as an example the 1st Middle-Polish Lignite Seam (MPLS-1) in the Jóźwin IIB opencast mine in central Poland. It should be mentioned here that any remarks in the present contribution concerning MPLS-1 refer exclusively to this lignite seam in the Jóźwin IIB opencast mine.

The investigated discontinuities consist of two sets, i.e. the face and butt cleats, which are roughly oriented NW-SE and NE-SW, respectively. The mean spacing of the face cleats is $\sim 12.4 \mathrm{~cm}$, while the mean spacing of the butt cleats is $\sim 12.8$ $\mathrm{cm}$. The maximum average aperture is $\sim 4.9 \mathrm{~mm}$ for the face cleats and $\sim 4.1 \mathrm{~mm}$ for the butt cleats. The cleat spacing and aperture do not depend on the lignite thickness, but the cleat spacing increases with increasing mineral-matter and xylite content, whereas the aperture increases when the contents decrease. The regional folding and local salt diapirism tentatively explain the formation of the orthogonal system of the lignite cleats, partly because of the parallelism of the face cleats and the major tectonic directions in central Poland.
\end{abstract}

Keywords: lignite cleats, structural geology, lignite seams, Miocene, central Poland

\section{Introduction}

Cleats are common within the mid-Miocene lignites in all Polish opencast mines. Jóźwin IIB is one of three opencast mines belonging to the Konin lignite mine, where the $1^{\text {st }}$ Middle-Polish Lignite Seam (MPLS-1) is currently exploited (Fig. 1). Almost $50 \%$ of the more than 10.1 million $\mathrm{Mg}$ of lignite extracted by the Konin lignite mine comes from the Jóźwin IIB opencast mine. The entire Polish lignite production exceeded 64.2 million Mg in 2012 (Pietraszewski, 2013).

Natural fractures in lignites have not been investigated systematically in Poland before, nor elsewhere. This is in contrast to hard coal, which are intensively examined, among other reasons because they contain coalbed methane - CBM (e.g. McCulloch et al., 1974, 1976; Close \& Mavor, 1991; Close, 1993; Law, 1993; Karacan \& Okandan, 2000; Su et al., 2001; Solano-Acosta et al., 2007; Dawson \& Esterle, 2010; Paul \& Chatterjee, 2011). The present contribution is the first to focus purely on discontinuities within the Miocene MPLS- 1 of central Poland.

The main objectives of the present contribution are (1) to define the cleats; (2) to present field research methods and a graphical presentation of the cleats; and (3) to provide and discuss the preliminary results of the cleat studies obtained from the Jóźwin IIB opencast mine. 


\section{Geological setting}

MPLS-1 is positioned in the relatively shallow tectonic depression constituting the Kleczew Graben. The lignite section examined in detail is situated in the northernmost part of the western, $\mathrm{S}-\mathrm{N}$ trending branch of the graben, which is located $\sim 20 \mathrm{~km} \mathrm{NNW}$ of Konin (Fig. 1).

The Cenozoic subsidence of the Kleczew Graben started after the Late Oligocene, when the entire territory of central Poland was subjected to uplift (Widera et al., 2008; Jarosiński et al., 2009; Widera \& Hałuszczak, 2011). Therefore, the Early-Middle Miocene sediments of the Koźmin Formation are present at the base of the Cenozoic succession in the study area (Fig. 2). This lithostratigraphical unit consists mainly of sand, with silt and clay and with thin (up to $1 \mathrm{~m}$ ) lignite intercalations. The siliciclastic deposits are on average $\sim 40 \mathrm{~m}$ thick.

The Koźmin Formation is overlain by the Poznan Formation, which is divided into the Middle-Polish and Wielkopolska members (Fig. 2). MPLS-1 belongs to the Middle-Polish Member. Moreover, so-called 'Grey Clays' with xylites and thin sandy intercalations occasionally accompany this lignite seam. Stratigraphically, MPLS-1 can be directly correlated

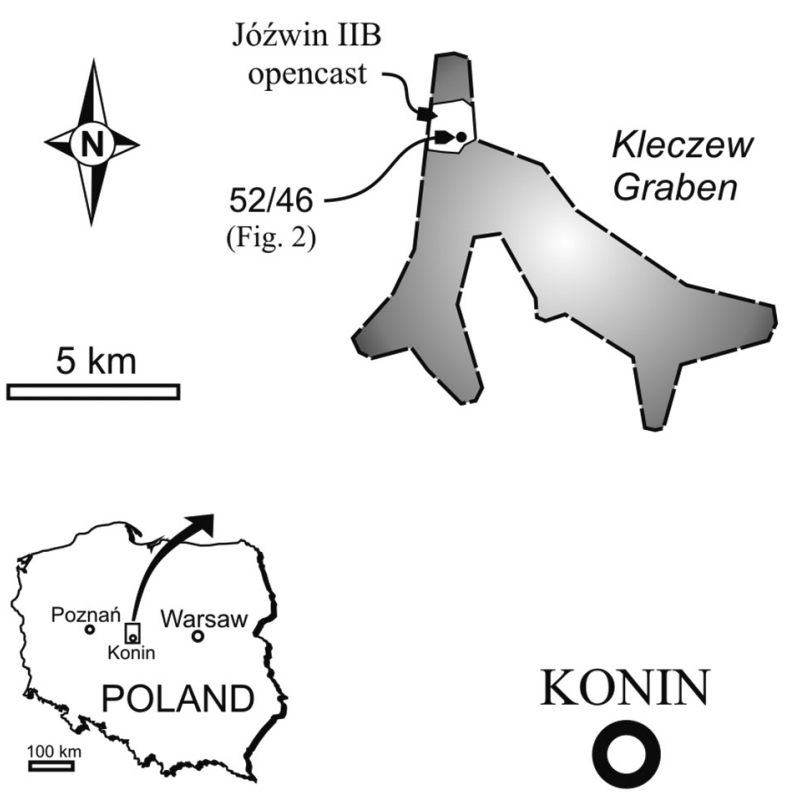

Fig. 1. Location map of the Jóźwin IIB lignite opencast mine in central Poland. with the $1^{\text {st }}$ Lusatian Lignite Horizon of SE Germany, both being of Middle Miocene age (cf. Sadowska \& Giża, 1991; Piwocki \& Ziembińska-Tworzydło, 1997; Ważyńska, 1998; Grimm, 2002; Widera et al., 2008). MPLS-1 is approx. 6-12 $\mathrm{m}$ thick, although it locally reaches a maximum thickness of $19.8 \mathrm{~m}$ in the study area (Piwocki, 1992).

Regardless of such parameters as calorific value, reflectance, sulphur content, and so on (Piwocki, 1987; Kwiecińska \& Wagner, 1997, 2001; Macuda et al., 2011), the most important in the context of the present research are the mineral matter and xylite content. MPLS1 from the Konin lignite mine is characterised by an average ash content, calculated on a dry basis, reaching up to $15.5 \mathrm{wt} \%$ (Kwiecińska \& Wagner, 1997). The lignite seam contains a relatively large amount of xylites $(3.8 \%$ on average) in the study area (Bielowicz, 2013). Obviously, the content of both mineral matter/ash and xylites is reflected in the composition of the lignite lithotype associations (Kwiecińska \& Wagner, 1997; Widera, 2012).

The upper part of the Poznan Formation, the Wielkopolska Member, overlies MPLS-1 (Fig. 2). This predominantly muddy (clay + silt $>50 \%$ ) lithostratigraphical unit is the uppermost part of the Neogene in central Poland. These fine-grained siliciclastic deposits are from a few metres to more than $30 \mathrm{~m}$ thick;

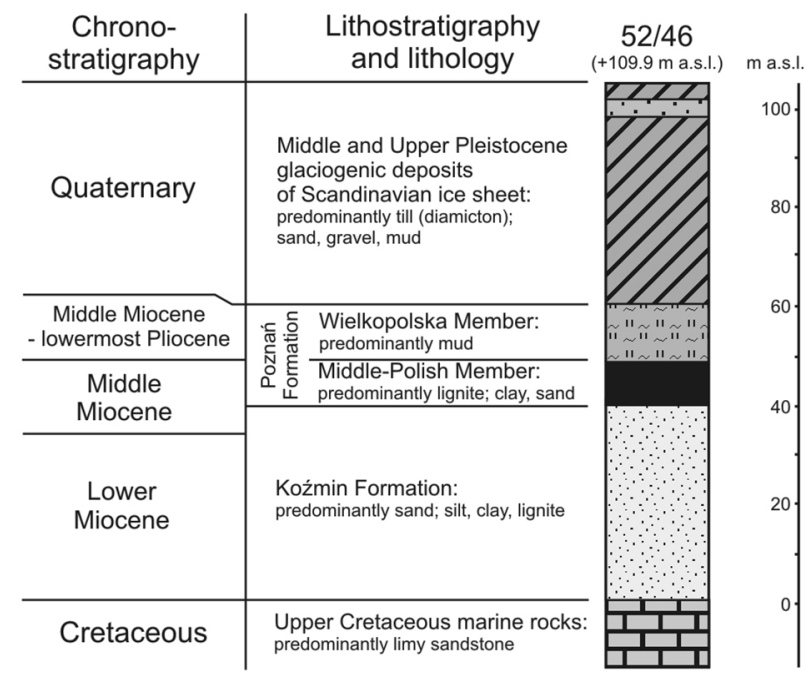

Fig. 2. Generalised lithostratigraphical section of borehole 52/46, which is representative for the study area. For location of the borehole, see Figure 1. 
the thickness differences are due to Pleistocene erosional processes (Widera, 2013a). Most likely, they were deposited in an anastomosing-river environment (Widera, 2013b), and their age extends from the late Mid-Miocene to the latest Early Pliocene (Piwocki \& Ziembinska-Tworzydło, 1997; Troć \& Sadowska, 2006). The Neogene, including MPLS-1, is covered by a Quaternary succession of $\sim 40 \mathrm{~m}$ thick, which consists mostly of Pleistocene tills (Fig. 2).

\section{Cleat nomenclature and classification}

For historical reasons, the nomenclature and classification of cleats is quite complex. They are defined below, giving their equivalent names and basic characteristics.

\subsection{Cleat definition}

In simple terms, cleats in coals correspond to the vertical fractures and/or joints in other sedimentary rocks (e.g. McCulloch et al., 1974; Laubach et al., 1998; Su et al., 2001). Cleats are natural opening-mode fractures that are almost perpendicular to the bottom and roof of the coal seam. They usually exist in two sets that in present-day terminology are called "face" and "butt" cleats. These two cleat sets are roughly perpendicular to each other and to the bedding (Fig. 3).

Due to their high permeability for gas and water, the interest in cleats dates back to the beginnings of coal mining. Already in 1834, Edward Mammatt described the fracture origin in coal for the first time (cf. McCulloch et al., 1974; Laubach et al., 1998). Over the years, different terminology has been used for coal cleats. Kendall \& Briggs (1933, p. 164), for example, reported that the most prominent cleat is called the "main cleat" or "master-joint cleat"; a set of cleats perpendicular to them was known as a "cross-cleat" or "board cleat" (Kendall \& Briggs, 1933; McCulloch et al., 1974). Additionally, miners divided fractures/ joints in coal into two groups, i.e. face and butt cleats. According to Nelson (1983, p. 39): "The

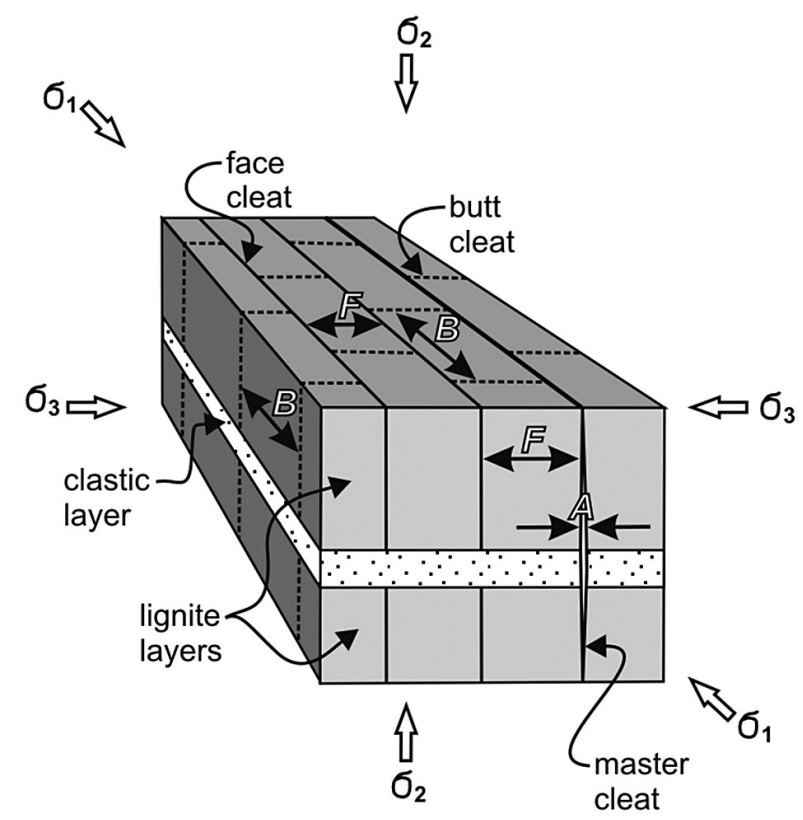

Fig. 3. Classical model of the formation of joints (cleats) in non-folded areas (according to Ting, 1977; Close, 1991, 1993; Jaroszewski, 1981; Hancock, 1985; Price \& Cosgrove, 1990; Dadlez \& Jaroszewski, 1994; Pollard \& Fletcher, 2005; Marshak \& Mitra, 2006). Note the principal stresses: $\sigma_{1}$ is the largest stress, $\sigma_{2}$ is the intermediate stress, $\sigma_{3}$ is the smallest stress. Cleat properties: A is cleat aperture, $\mathrm{F}$ is face-cleat spacing, B is butt-cleat spacing.

terms face and butt cleat come from the days of hand loading. Coal was easier to cut when mined with the prominent cleat parallel and the secondary cleat at right angles to the face".

\subsection{Cleat properties}

Cleats are characterised by geometrical properties that include orientation, spacing, aperture, height, length, connectedness, and so on. The present study focuses only on the first three of them, because they can be easily and directly measured in the field.

Cleat orientation should be understood as the strike of the cleat walls. In this case, the cleat strikes representing an individual set are close to each other, as opposed to the cleat orientation representing the other set (Fig. 3). The cleat spacing is defined as the perpendicular distance between two neighbouring cleats of the same set. The aperture is the distance between the walls of a single cleat (Fig. 3). 


\subsection{Genetic cleat classification}

The origin of cleats is still under discussion. Some researchers believe that cleats have a tectonic origin, while others suggest a non-tectonic origin (cf. McCulloch et al., 1974, p. 3; Laubach et al., 1998, p. 195-201; Su et al., 2001, p. 56-58). The tectonic and non-tectonic hypotheses have been combined by Ammosov \& Eremin (1963, p. 4). They distinguished two types of fractures in coals, namely 'endogenic' and 'exogenic' cleats. The former type represents those cleats which developed during the coalification process, i.e. by dehydration, devolatilisation, matrix shrinkage, and so on. In contrast, the latter type represents cleats resulting from external forces such as tectonics. Regardless of the suggested 'endogenic' processes, at least the cleat orientation seems to be controlled by the tectonic stress field (Laubach et al., 1998; Su et al., 2001; Solano-Acosta et al., 2007; Dawson \& Esterle, 2010; Paul \& Chatterjee, 2011; and references therein).

Additionally, Ammosov \& Eremin (1963) classified the fractures in coals based on relative cleat spacing. They identified four groups of cleats that correspond to the following: Group 1 and 2 are macrocleats, measured in deci- and centimetres, respectively; Group 3 consists of mesocleats, measured in millimetres; and Group 4 are microcleats, measured in micrometers (cf. table 1 of Solano-Acosta et al., 2007). In the present study, only macrocleats belonging mainly to Group 2 of Ammosov \& Eremin (1963) are described.

\section{Methods}

Cleats can be studied by the same methods used for structural analysis of fractures and joints in non-coal rocks. These methods can be found in any standard text-books on structural geology (e.g., Billings, 1972; Jaroszewski, 1981; Price \& Cosgrove, 1990; Twiss \& Moores, 1992; Dadlez \& Jaroszewski, 1994; Pollard \& Fletcher, 2005; Marshak \& Mitra, 2006).

\subsection{Field studies}

Field studies in the Jóźwin IIB lignite opencast mine played a key role during the implementation of this investigation during 20122013. The cleat properties were determined on the basis of vertical and 'fresh' lignite walls using a hand-held compass and a tape. Moreover, a large number of photographs were taken, some of which are presented in this contribution. In total, 237 measurements were made, comprising 124 cleat orientations, 66 cleat spacings, and 47 cleat apertures. The average values of these cleat properties were finally calculated using Microsoft Office Excel 2003.

Additionally, both in the field and during the documentation of sections of MPLS-1, codes for lignite lithotypes were applied that had earlier been proposed by the present author (Widera, 2012). In the case of the clastic lithofacies, however, the commonly known codes established by Miall (1977) were used for the non-coal deposits accompanying MPLS-1. Both lithotype and lithofacies codes are presented in Table 1.

\subsection{Graphic presentation}

In general, all methods of graphic presentation of joints and fractures which are dealt with in text-books on structural geology can be used for cleats. However, the two methods the au-

Table 1. Codes for the lignite lithotypes (according to Widera, 2012) and for the lithofacies (according to Miall, 1977).

\begin{tabular}{ll}
\multicolumn{1}{c}{ Code } & \multicolumn{1}{c}{ Lignite lithotype } \\
\hline DLm & $\begin{array}{l}\text { detritic lignite with a massive structure } \\
\text { detritic lignite with a massive } \\
\text { and fractured structure } \\
\text { DLm(fr) }\end{array}$ \\
DXLm & $\begin{array}{l}\text { detro-xylitic lignite with a massive structure } \\
\text { detro-xylitic lignite with a massive } \\
\text { and fractured structure }\end{array}$ \\
DXLm(fr) \\
XDLm(fr) & $\begin{array}{l}\text { xylo-detritic lignite with a massive } \\
\text { and fractured structure }\end{array}$ \\
\hline Code & Lithofacies \\
\hline Sm & sand with a massive structure \\
STm & silty sand with a massive structure \\
\hline
\end{tabular}


Table 2. Cleat-property measurements for MPLS-1 in the Jóźwin IIB opencast mine.

\begin{tabular}{lccc|}
\hline & $\begin{array}{c}\text { Measure- } \\
\text { ments } \\
\text { (number) }\end{array}$ & Min.-max. & Average \\
\hline \multicolumn{4}{c}{ Face cleats } \\
\hline orientation $\left(^{\circ}\right)$ & 67 & $95-174$ & 134.8 \\
\hline spacing $(\mathrm{cm})$ & 41 & $10.3-13.9$ & 12.4 \\
aperture $(\mathrm{mm})$ & 26 & $0-15$ & 4.9 \\
\hline \multicolumn{4}{c}{} \\
\hline orientation $\left(^{\circ}\right)$ & 57 & $6-82$ & 44.7 \\
\hline spacing $(\mathrm{cm})$ & 25 & $9.3-14.7$ & 12.8 \\
aperture $(\mathrm{mm})$ & 21 & $0-13$ & 4.1 \\
\hline
\end{tabular}

thor considered most suitable to achieve the objectives were selected for the present work. The first is the histogram, which is applied for the spacing and cleat aperture, and the second is the rose diagram, which is applied for cleat dip and orientation. As a supplement, all basic statistical data for cleat measurements are summarised in Table 2.

\section{Results}

Macroscopic description of the lignite lithotypes is the basis for further structural analysis of the cleats. This will set out indicatively the relationship between the mineral matter and xylites content on the one hand and the main cleat properties on the other hand. The cleat properties are described separately for the face and butt cleats.

\subsection{General description of the lignite seam}

The studied section of MPLS-1 is located in the south-eastern part of the Jóźwin IIB opencast mine (Fig. 1). Due to good accessibility, the lowermost 2-3 $\mathrm{m}$ of this lignite seam could be investigated in detail. The estimated altitude of this section ranges from $\sim 37 \mathrm{~m}$ to $\sim 40 \mathrm{~m}$ a.s.l. (Fig. 4).

Five lignite lithotypes and two lithofacies were distinguished (Fig. 4; Table 1). The lignites were grouped in detritic (DL), detro-xylitic (DXL), and xylo-detritic (XDL) lignite lithotype associations. The clastic deposits represent two lithofacies, namely sand and silty sand, both with a massive structure (Table 1).

The section of MPLS-1 starts with detritic lignite with a massive structure, i.e. DLm (Fig. $4)$. This is one of the lignite layers in which cleats and other fractures do not occur. This lignite is overlain by a massive association of detro-xylitic lignite (DXLm) and a massive association of detro-xylitic lignite with fractures DXLm(fr). Two layers of lithotype DXLm(fr)

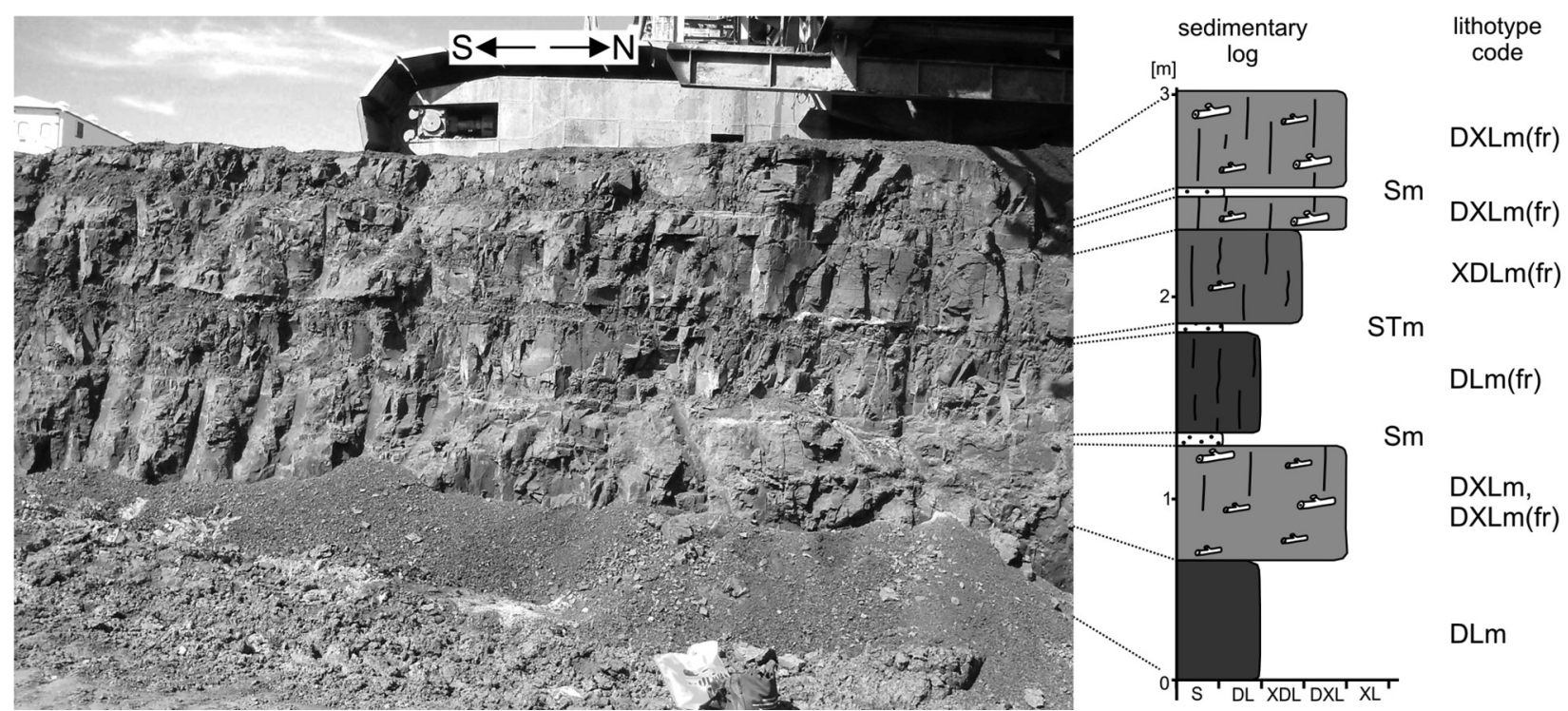

Fig. 4. General view of the section of the $1^{\text {st }}$ Middle Polish Lignite Seam with its sedimentary log. For explanation of the lignite lithotype codes, see Table 1. 


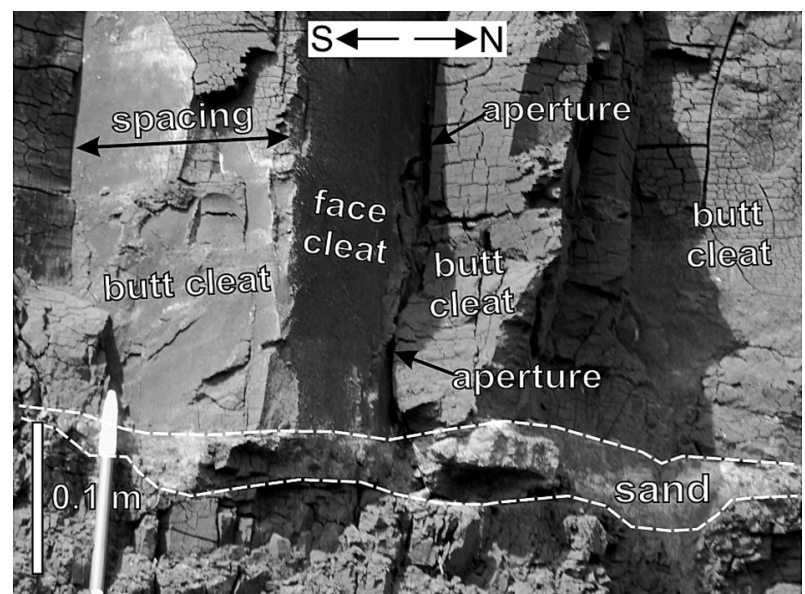

Fig. 5. Detailed view of the $1^{\text {st }}$ Middle Polish Lignite Seam showing the well-developed face and butt cleats with their basic properties. Note the sandy intercalation that separates the two layers of fractured lignite.

also occur at the top of the investigated part of MPLS-1. In the middle of the section, detritic and xylo-detritic lignites are present with a massive and fractured structure, DLm(fr) and XDLm(fr), respectively. It is noteworthy that these lignite lithotypes are occasionally interrupted by thin (up to $10 \mathrm{~cm}$ ) sands and silty sands (Figs 4, 5).

\subsection{Cleat measurements}

MPLS-1 consists in the Jóźwin IIB opencast mine of face and butt cleats. Measurements of their properties amounted, for the cleat orientation, to 67 and 57, respectively; for the cleat spacing to 41 and 25, respectively, and for the cleat aperture to 26 and 21, respectively (Figs 6, 7; Table 2).

\subsubsection{Face cleats}

On average, the face-cleat orientation is $134.8^{\circ}$, with a standard deviation of $\sim 11.9^{\circ}$. These cleats dip steeply $\left(75^{\circ}-90^{\circ}\right)$, averaging $86.6^{\circ}$ (Fig. 6A)

The face-cleat spacing (Fig. 5) ranges from $10.3 \mathrm{~cm}$ to $13.9 \mathrm{~cm}$; the average value is 12.4 $\mathrm{cm}$ (Table 2). As shown in the histogram, the spacing shows an almost log-normal distribution (Fig. 6B).

The face-cleat aperture (Fig. 5) is $0-15 \mathrm{~mm}$; its average value is $4.9 \mathrm{~mm}$ (Table 2). It must be
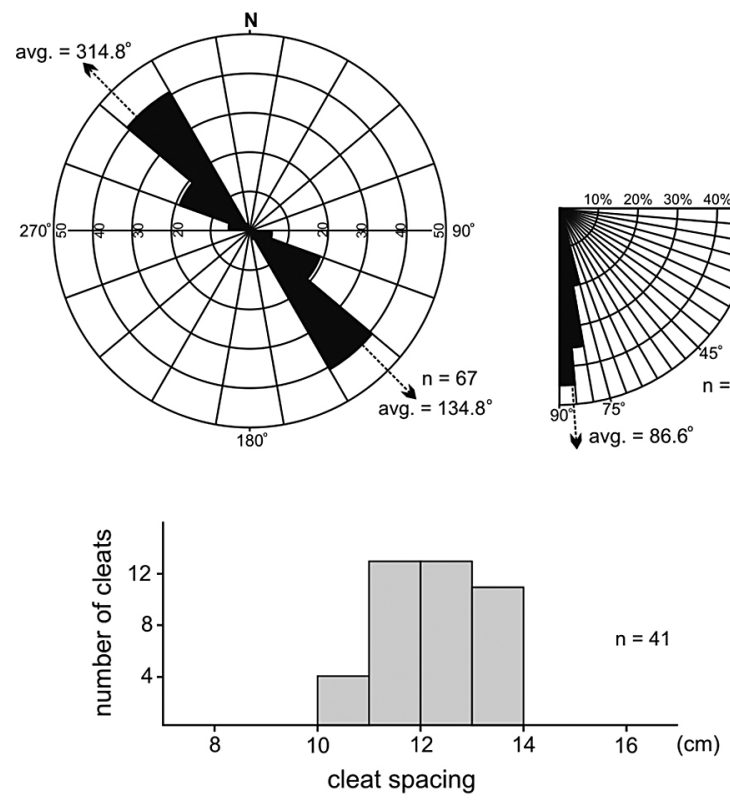

B

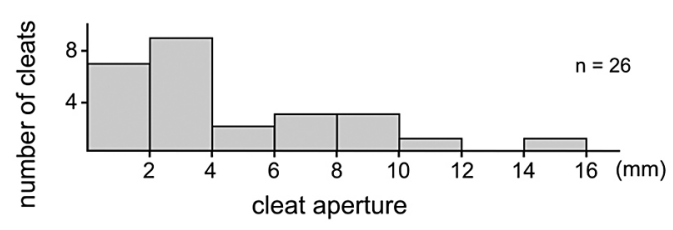

C

Fig. 6. Face cleat measurements.

A: Orientations and dips of the cleats; B: Distributions of the cleat spacing; C: Distributions of the cleat aperture.

emphasised in this context that, as in the case of the butt cleats, the aperture measurements refer to the largest distance between the two sides of the fissure/cleat. It is also noteworthy that the distribution of the face-cleat aperture is irregular (Fig. 6C).

\subsubsection{Butt cleats}

The average strike of the butt cleats is exactly $44.7^{\circ}$ and the standard deviation of the orientation is $\sim 11.9^{\circ}$. These cleats also dip steeply $\left(75^{\circ}-90^{\circ}\right)$, with a mean value of $86.3^{\circ}$ (Fig. $7 \mathrm{~A}$ ).

The spacing of these cleats (Fig. 5) ranges between $9.3 \mathrm{~cm}$ and $14.7 \mathrm{~cm}$; the average value is $12.8 \mathrm{~cm}$ (Table 2). The spacing is relatively close to a log-normal distribution (Fig. 7B).

The butt-cleat aperture (Fig. 5) ranges from $0 \mathrm{~mm}$ to $13 \mathrm{~mm}$, with an average value of 4.1 $\mathrm{mm}$ (Table 2). The aperture of this set of cleats does not clearly show a log-normal distribution (Fig. 7C). 

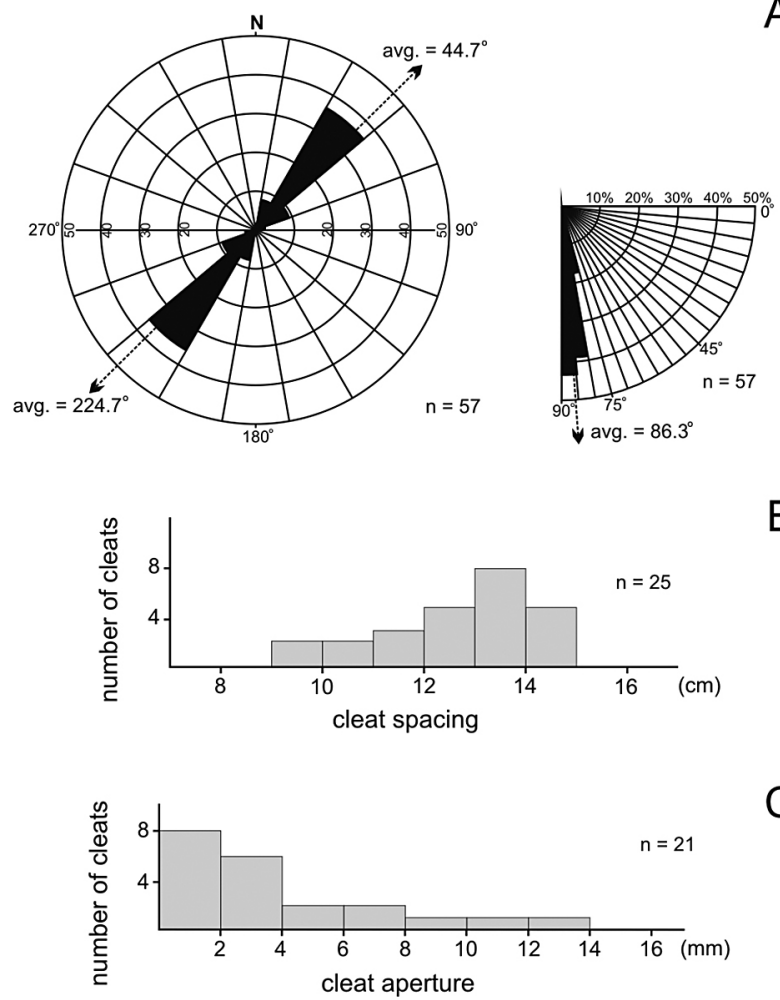

B

Fig. 7. Butt cleat measurements.

A: Orientations and dips of the cleats; B: Distributions of the cleat spacing; C: Distributions of the cleat aperture.

\section{Interpretation and discussion}

The face and butt cleats within MPLS- 1 are almost exactly perpendicular to each other: the difference between their average azimuth directions is $90.1^{\circ}$ (Figs 6A, 7A; Table 2). Therefore, they form an orthogonal ideal cleat (joint) system, which is close to $90^{\circ}$, as defined by McCulloch et al. (1976).

The face-cleat orientation is parallel to the main tectonic directions in central Poland, which are oriented from NW to SE. In general, both the regional tectonic units (synclines, anticlines) and local salt structures (pillows, diapirs) represent folds at various scales. Their axes are distinctly striking NW-SE (Dadlez et al., 2000; Karnkowski, 2008). This direction seems to be inherited from the pre-Cenozoic tectonics in the study area. In accordance with the classical model of the formation of cleats/ joints in tectonically non-deformed rocks, as shown in Figure 3, the largest principal stress (compression direction) should also be parallel to the face cleats (e.g. McCulloch et al., 1974; Jaroszewski, 1981; Hancock, 1985; Price \& Cosgrove, 1990; Close \& Mavor, 1991; Close, 1993; Ting, 1977; Dadlez \& Jaroszewski, 1994; Pollard \& Fletcher, 2005; Marshak \& Mitra, 2006; and references therein). Consequently, the folded structures should be directed perpendicular to the largest principal stress, i.e. NE-SW. Actually, however, they are oriented NW-SE. The cleat system (two orthogonal sets of cleats/ extensional fractures) can consequently not be explained by the classical model. This leaves two options for an explanation. The first is that the face cleats may have formed in the hinge zone of the fold, where extension is perpendicular to the anticline axis. The second is that the face cleats may have been created, for instance, above a rising salt pillow. The latter explanation is supported by both well-developed sets of cleats within MPLS-1. In both options the resulting face cleats are oriented NW-SE, but the strike of the butt cleats is NE-WS (Figs 6A, 7A; Table 2).

The spacing of the face cleats is more regular than that of the butt cleats. The average spacings are very close, viz. $12.4 \mathrm{~cm}$ and 12.8 $\mathrm{cm}$, respectively (Table 2 ). This is also well visible in the histograms, where the spacings of the two cleat types show almost log-normal and close to the log-normal distributions, respectively (cf. Figs 6B and 7B).

A relationship between the cleat spacing and the thickness of the lignite layer/lithotype has not been found for MPLS-1. However, the cleats are better developed in layers containing more fine-detrital matter and less xylites. Thus, most measurements of the cleat properties come from the DLm(fr) and XDLm(fr), i.e. detritic and xylo-detritic lignite lithotypes with a massive and fractured structure (Figs 4, 5, 8; Table 1).

The role of mineral matter/ash in the cleat development is also interesting. Macroscopic observations in the field made clear that an increase in the content of inorganic material increases the distance between successive cleats. This is particularly clear in the case of mineral intercalations, where the non-organic layers (sands and/or silty sands) almost always terminate the continuity of the cleats (Fig. 8). 


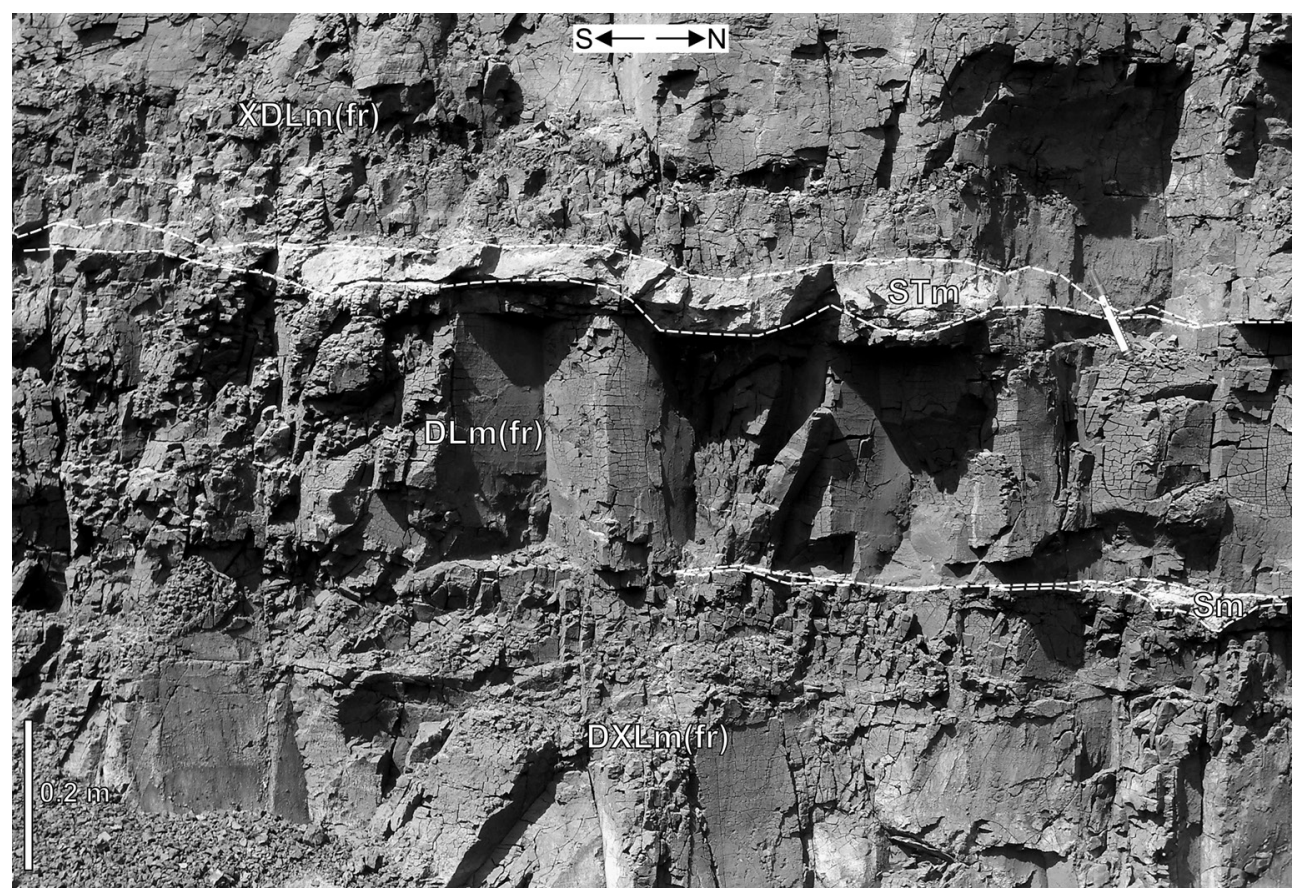

Fig. 8. Relationship between the lignite lithotype and cleat development. Note the clastic layers that terminate the cleat. For explanation of the lignite lithotype codes, see Table 1.

There is no observable relationship between cleat aperture and cleat spacing or the thickness of the lignite layers within MPLS-1. It appears that the cleat aperture strictly depends on the content of mineral matter and xylites. The cleat aperture is therefore best developed within the detritic lignite lithotypes with a massive and fractured structure, DLm(fr), which contains relatively small amounts of xylites and mineral matter (Fig. 8).

\section{Conclusions}

The $1^{\text {st }}$ Middle-Polish Lignite Seam (MPLS1) of mid-Miocene age is characterised by a relatively large amount of fractures/joints, socalled cleats. Cleat measurements for further studies were made in the Jóźwin IIB lignite opencast mine in central Poland.

The investigated discontinuities within MPLS-1 form two sets that are termed the 'face' and 'butt' cleats. They are perpendicular to the bedding and to each other; therefore, they represent an orthogonal cleat system. The face cleats are directed NW-SE, while the butt cleats strike NE-SW.

The cleat spacing is quite regular, averaging $12.4 \mathrm{~cm}$ for the face cleats and $12.8 \mathrm{~cm}$ for the butt cleats. The average cleat apertures are 4.9 $\mathrm{mm}$ and $4.1 \mathrm{~mm}$, respectively. No relationship exists between cleat spacing and aperture on the one hand and the thickness of the lignite layers on the other hand. The spacing and aperture depend rather on the content of mineral matter and xylites. Thus, the lignite layers/ lithotypes with low mineral matter content and xylites have the best-developed cleats.

Finally, the face-cleat orientation is linked with older, pre-Cenozoic tectonic directions that are oriented NW-SE in central Poland. Most probably, both the face and butt cleats within MPLS-1 were formed in the hinge zone of regional folds or above locally rising salt structures such as, for instance, pillows.

\section{Acknowledgements}

The author wishes to thank the reviewers for their helpful evaluation of the manuscript.

\section{References}

Ammosov, I.I. \& Eremin, I.V., 1963. Fracturing in coal. IZDAT Publishers (Moscow) / Office of Technical Services, U.S. Department of Commerce (Washington, DC), 109 pp.

Bielowicz, B., 2013. Petrographic composition of Polish lignite and its possible use in a fluidized bed gasifi- 
cation process. International Journal of Coal Geology 116-117, 236-246.

Billings, M.P., 1972. Structural geology (3rd ed.)., Prentice Hall (New Delhi), 606 pp.

Close, J.C., 1993. Natural fractures in coal. [In:] Law, B.E. \& Rice, D.D. (Eds), Hydrocarbons from coal. American Association of Petroleum Geologists Studies in Geology 38, 119-132.

Close, J.C. \& Mavor, M.J., 1991. Influence of coal composition and rank on fracture development in Fruitland coal gas reservoirs of San Juan Basin. [In:] Schwochow, S.D. (Ed.), Coalbed methane of western North America. Rocky Mountain Association of Geologists, 109-121.

Dadlez, R. \& Jaroszewski, W., 1994. Tektonika [Tectonics]. Polish Geological Press (Warszawa), 743 pp. (in Polish)

Dadlez, R., Marek, S. \& Pokorski, J., 2000. Geological map of Poland without Cenozoic deposits, scale 1:1000000. Polish Geological Institute (Warszawa).

Dawson, G.K.W. \& Esterle, J.S., 2010. Controls on coal cleat spacing. International Journal of Coal Geology 82, 213-218.

Grimm, K. (Ed.), 2002. Tertiary. [In:] German Stratigraphic Commission (Ed.): Stratigraphic table of Germany 2002. GFZ GeoForschungsZentrum (Potsdam), 14 pp.

Hancock, P., 1985. Brittle microtectonics: principles and practice. Structural Geology 7, 437-458.

Jarosiński, M., Porawa, P. \& Ziegler, P.A., 2009. Cenozoic dynamic evolution of the Polish Platform. Geological Quarterly 53, 3-26.

Jaroszewski, W., 1981. Tektonika uskoków i fałdów [Fault and fold tectonics]. Geological Press (Warszawa), 360 pp. (in Polish)

Karacan, C.Ö. \& Okandan, E., 2000. Fracture/cleat analysis of coals from Zonguldak Basin (northwestern Turkey) relative to the potential of coalbed methane production. International Journal of Coal Geology 44, 109-125.

Karnkowski, P.H., 2008. Regionalizacja tektoniczna Polski - Niż Polski [Tectonic subdivision of Poland - Polish Lowlands]. Przeglad Geologiczny 56, 895-903. (in Polish)

Kendall, P.F. \& Briggs, H., 1933. The formation of rock joints and the cleat of coal. Proceedings of the Royal Society, Edinburgh 53, 164-187.

Kwiecińska, B. \& Wagner, M., 1997. Typizacja cech jakościowych węgla brunatnego z krajowych złóż wedtug kryteriów petrograficznych $i$ chemiczno-technologicznych dla celów dokumentacji geologicznej złóż oraz obsługi kopalń [Classification of qualitative features of brown coal from Polish deposits according to petrographical, chemical and technological criteria]. Wydawnictwo Centrum PPGSMiE Polskiej Akademii Nauk (Kraków), 87 pp. (in Polish)

Kwiecińska, B. \& Wagner, M., 2001. Możliwość zastosowania refleksyjności jako metody badawczej w klasyfikowaniu i technologicznej ocenie jakości węgla brunatnego [Application of reflectance in the natural and technological classification of brown coal]. Wydawnictwo Akademii Górniczo-Hutniczej (Kraków), 35 pp. (in Polish)
Laubach, S.E, Marrett, R.A., Olson, J.E. \& Scott, A.R., 1998. Characteristics and origins of coal cleat: a review. International Journal of Coal Geology 35, 175-207.

Law, B.E., 1993. The Relationship between coal rank and cleat spacing: implications for the prediction of permeability in coal. Proceedings of International Coalbed Methane Symposium II, the University of Alabama (Tuscaloosa), 435-441.

Macuda, J., Nodzeński, A., Wagner, M. \& Zawisza, L., 2011. Sorption of methane on lignite from Polish deposits. International Journal of Coal Geology 87, 41-48.

Marshak, S. \& Mitra, G., 2006. Basic methods of structural geology (2nd ed.)., Prentice Hall (New Jersey), 446 pp.

McCulloch, C.M., Deul, M. \& Jeran, P.W., 1974. Cleats in bituminous coalbeds. U.S. Bureau of Mines Report of Investigations Report 7910, 23 pp.

McCulloch, C.M., Lambert, S.W. \& White, J.R., 1976. Determining cleat orientations of deeper coalbeds from overlying coals. U.S. Bureau of Mines Report of Investigations Report 8116, 24 pp.

Miall, A.D., 1977. A review of the braided-river depositional environment. Earth-Science Reviews 13, 1-62.

Nelson, W.J., 1983. Geologic disturbances in Illinois coal seams. Illinois State Geological Survey Circular 530, 50 pp.

Paul, S. \& Chatterjee, R., 2011. Determination of in-situ stress direction from cleat orientation mapping for coal bed methane exploration in south-eastern part of Jharia coalfield, India. International Journal of Coal Geology 87, 87-96.

Pietraszewski, A., 2013. Polskie górnictwo węgla brunatnego w 2012 roku [Polish lignite mining industry in 2012]. Wegiel Brunatny 82, http:/ / www.ppwb.org.pl/ wb/82/2.php. (in Polish)

Piwocki, M., 1992. Zasięg i korelacja głównych grup trzeciorzędowych pokładów węgla brunatnego na platformowym obszarze Polski [Extent and correlations of main groups of the Tertiary lignite seams on Polish platform area]. Przegląd Geologiczny 40, 281-286. (in Polish)

Piwocki, M., 1987. Chemiczne i technologiczne właściwości głównych trzeciorzędowych grup pokładów węgla brunatnego w Polsce [Chemical and technological properties of the main groups of Tertiary brown coal seams in Poland]. Biuletyn Instytutu Geologicznego 357, 41-60. (in Polish)

Piwocki, M. \& Ziembińska-Tworzydło, M., 1997. Neogene of the Polish Lowlands - lithostratigraphy and pollen-spore zones. Geological Quarterly 41, 21-40.

Pollard, D.D. \& Fletcher, R.C., 2005. Fundamentals of structural geology. Cambridge University Press (Cambridge), $500 \mathrm{pp}$.

Price, N. \& Cosgrove, J., 1990. Analysis of geological structures. Cambridge University Press (Cambridge), 502 pp.

Sadowska, A. \& Giża, B., 1991. Flora i wiek węgla brunatnego $\mathrm{z}$ Patnowa [The flora and age of the brown coal from Pątnów]. Acta Palaeobotanica 31, 201-214. (in Polish)

Solano-Acosta, W., Mastalerz, M. \& Schimmelmann, A., 2007. Cleats and their relation to geologic lineaments 
and coalbed methane potential in Pennsylvanian coals in Indiana. International Journal of Coal Geology 72, 187-208

Su, X., Feng, Y., Chen, J. \& Pan, J., 2001. The characteristics and origins of cleat in coal from Western North China. International Journal of Coal Geology 47, 51-62.

Ting, F.T.C., 1977. Origin and spacing of cleats in coal beds. Journal of Pressure Vessel Technical Transactions ASME 99, 624-626.

Troć, M. \& Sadowska, A., 2006. Wiek formacji poznańskiej na obszarze Poznania [The age of the Poznan Formation in the Poznań region]. Przeglad Geologiczny 54, 588-593. (in Polish)

Twiss, R.J. \& Moores, E.M., 1992. Structural geology. W.H. Freeman \& Company (New York), 532 pp.

Ważyńska, H. (Ed.), 1998. Palynology and palaeogeography of the Neogene in Polish Lowlands. Prace Panstwowego Instytutu Geologicznego 160, 1-41. (in Polish)

Widera, M., 2012. Macroscopic lithotype characterisation of the 1st Middle-Polish (1st Lusatian) Lignite Seam in the Miocene of central Poland. Geologos 18, 1-11.
Widera, M., 2013a. Changes of the lignite seam architecture - a case study from Polish lignite deposits. International Journal of Coal Geology 114, 60-73.

Widera, M., 2013b. Sand- and mud-filled fluvial palaeochannels in the Wielkopolska Member of the Neogene Poznań Formation, central Poland. Annales Societatis Geologorum Poloniae 83, 19-28.

Widera, M., Ćwikliński W. \& Karman R., 2008. Cenozoic tectonic evolution of the Poznań-Oleśnica Fault Zone, central-western Poland. Acta Geologica Polonica 58, 455-471.

Widera, M. \& Hałuszczak, A., 2011. Stages of the Cenozoic tectonics in central Poland: examples from selected grabens. Zeitschrift der Deutschen Gesellschaft für Geowissenschaften 162, 203-214.

Manuscript received: 12 December 2013 Revision accepted: 25 January 2014 